Article

\title{
Exploration on Structural and Optical Properties of Nanocrystalline Cellulose/Poly(3,4-Ethylenedioxythiophene) Thin Film for Potential Plasmonic Sensing Application
}

\author{
Nur Syahira Md Ramdzan ${ }^{1}$, Yap Wing Fen ${ }^{1,2, *}$, Josephine Ying Chyi Liew ${ }^{1} \oplus$, Nur Alia Sheh Omar ${ }^{1}$, \\ Nur Ain Asyiqin Anas ${ }^{3}$, Wan Mohd Ebtisyam Mustaqim Mohd Daniyal ${ }^{2}$ and Nurul Illya Muhamad Fauzi ${ }^{2}$ \\ 1 Department of Physics, Faculty of Science, Universiti Putra Malaysia UPM, Serdang 43400, Selangor, \\ Malaysia; nursyahira.upm@gmail.com (N.S.M.R.); josephine@upm.edu.my (J.Y.C.L.); \\ nuralia_so@upm.edu.my (N.A.S.O.) \\ 2 Functional Devices Laboratory, Institute of Advanced Technology, Universiti Putra Malaysia UPM, \\ Serdang 43400, Selangor, Malaysia; wanmdsyam@gmail.com (W.M.E.M.M.D.); \\ illyafauzi97@gmail.com (N.I.M.F.) \\ 3 Physics Unit, Centre of Foundation Studies for Agricultural Science, Universiti Putra Malaysia UPM, \\ Serdang 43400, Selangor, Malaysia; ainasyiqin@upm.edu.my \\ * Correspondence: yapwingfen@upm.edu.my
}

check for updates

Citation: Ramdzan, N.S.M.; Fen, Y.W.; Liew, J.Y.C.; Omar, N.A.S.; Anas, N.A.A.; Daniyal, W.M.E.M.M.; Fauzi, N.I.M. Exploration on Structural and Optical Properties of Nanocrystalline Cellulose/Poly(3,4-

Ethylenedioxythiophene) Thin Film for Potential Plasmonic Sensing

Application. Photonics 2021, 8, 419. https://doi.org/10.3390/

photonics 8100419

Received: 28 August 2021

Accepted: 20 September 2021

Published: 29 September 2021

Publisher's Note: MDPI stays neutral with regard to jurisdictional claims in published maps and institutional affiliations.

Copyright: (c) 2021 by the authors. Licensee MDPI, Basel, Switzerland. This article is an open access article distributed under the terms and conditions of the Creative Commons Attribution (CC BY) license (https:/ / creativecommons.org/licenses/by/ $4.0 /)$.
Abstract: There are extensive studies on the development of composite solutions involving various types of materials. Therefore, this works aims to incorporate two polymers of nanocrystalline cellulose (NCC) and poly(3,4-ethylenethiophene) (PEDOT) to develop a composite thin film via the spin-coating method. Then, Fourier transform infrared (FTIR) spectroscopy is employed to confirm the functional groups of the NCC/PEDOT thin film. The atomic force microscopy (AFM) results revealed a relatively homogeneous surface with the roughness of the NCC/PEDOT thin film being slightly higher compared with individual thin films. Meanwhile, the ultraviolet/visible (UV/vis) spectrometer evaluated the optical properties of synthesized thin films, where the absorbance peaks can be observed around a wavelength of 220 to $700 \mathrm{~nm}$. An optical band gap of $4.082 \mathrm{eV}$ was obtained for the composite thin film, which is slightly lower as compared with a single material thin film. The NCC/PEDOT thin film was also incorporated into a plasmonic sensor based on the surface plasmon resonance principle to evaluate the potential for sensing mercury ions in an aqueous medium. Resultantly, the NCC/PEDOT thin film shows a positive response in detecting the various concentrations of mercury ions. In conclusion, this work has successfully developed a new sensing layer in fabricating an effective and potential heavy metal ions sensor.

Keywords: nanocrystalline cellulose; poly(3,4-ethylenedioxythiophene); structural properties; optical properties; surface plasmon resonance

\section{Introduction}

To achieve success in research or experiment, the selection of materials and methods is very significant to ensure the project will be able to accomplish its objectives at the end of the process. Therefore, until recently. researchers have always sought the novelty of materials as a fundamental property to verify the quality of research. Hence, nanocrystalline cellulose (NCC) is one of the novel materials that has been intensively studied in recent years. This biopolymer is a cellulose nanocrystal that has a diameter of $1-5 \mathrm{~nm}$ and a length of 150-300 nm [1,2]. As the highlight, it can be synthesized from a variety of natural resources via an acid hydrolysis process [3,4]. Owing to many beneficial properties such as biodegradability, biocompatibility, and low toxicity [5-8], this material has great potential to be applied in various fields including industrial sectors, drug delivery systems, pharmaceutical industries, and sensors [9-16]. However, the potential of NCC can be 
seen to be further developed through incorporation with other materials to enhance the effectiveness and usefulness in certain fields.

On the other hand, conducting polymers have gained tremendous attention from researchers owing to their unique characteristics. Although there are several examples of conducting polymers, for instance, polyaniline and polypyrrole, poly(3,4-ethylenedioxythiophene) (PEDOT), which is selected for this work $[17,18]$, has additional properties. Compared with other conducting polymers, PEDOT possesses excellent properties thanks to its good conductivity, excellent chemical and electrochemical properties, and high transparency [19-27]. Therefore, in light of these advantages, this polymer has been largely explored for a wide range of applications including batteries, transistors, light-emitting diodes (LEDs), and optical sensors [28-31]. Ravit et al. (2019) had successfully investigated the combination of NCC and PEDOT film using the electrochemical polymerization method to develop a supercapacitor [32]. However, as far as we are aware, there is no published work on this synthesized thin film as a sensing layer for the plasmonic sensor for metal ions' detection. In addition, optical spectroscopy including photoluminescence, inductively coupled plasma mass spectroscopy (ICP-MS), optical metasurfaces-based sensor, and surface-enhanced Raman spectroscopy (SPR) is hampered by some drawbacks [33-36]. Surface plasmon resonance (SPR) is a simple and sensitive plasmonic-based sensor, where it is considered as one of the complementary sensors that offer excellent potential sensing. Furthermore, it has advantageous characteristics such as inexpensive, rapid response time, label-free technique, high sensitivity, and the ability to detect the analyte at very low concentrations. In this plasmonic-based sensor, several configurations have been introduced include grating coupler [37], optical fiber-based [38,39], optical waveguide system [40], and prism coupler $[41,42]$. The Kretschmann configuration in a prism-based system is commonly used because the metal thin film is attached directly to the prism without any gap. This sensor has been applied in numerous studies for various kinds of detection such as dengue viruses [43-45], glucose [46,47], heavy metal ions [48-54], and phenol [55,56].

Hence, as part of this research, the NCC/PEDOT thin film was prepared via the spin-coating method, followed by its further characterization to analyze the structural and optical properties using atomic force microscopy (AFM), Fourier transform infrared (FTIR), and ultraviolet/visible (UV/vis) spectroscopy. Then, the composite material will be incorporated into a plasmonic sensor based on SPR to determine its potential as a sensing thin film. The potential sensing of the NCC/PEDOT thin film will be observed and proven based on the graph of reflectance against the incidence angle when in contact with various concentrations of the analyte.

\section{Experimental Section}

2.1. Materials and Reagents

Nanocrystalline cellulose (NCC) powder, mercury standard solution, and poly $(3,4-$ ethylenedioxythiophene)-poly(styrenesulfonate) (PEDOT/PSS) were supplied by SigmaAldrich (St. Louis, MO, USA). All the chemicals used in this experiment were of analytical grade and were used without further purification. Then, a high refractive index prism of 1.77861 at $632.8 \mathrm{~nm}$ and glass coverslips $(24 \mathrm{~mm} \times 24 \mathrm{~mm} \times 0.1 \mathrm{~mm})$ were purchased from Menzel-Glaser (Braunschweig, Germany) and used as received.

\subsection{Preparation of Thin Film and Analyte}

To prepare the thin film, initially, $5 \mathrm{~g}$ of NCC was dissolved in $100 \mathrm{~mL}$ of deionized water and stirred for $24 \mathrm{~h}$ using a magnetic stirrer to ensure that the powered NCC was fully dissolved. Later, the composite solution of NCC/PEDOT was synthesized by mixing $1 \mathrm{~mL}$ of the prepared NCC solution with $1 \mathrm{~mL}$ of the commercially purchased PEDOT/PSS solution, and the resulting mixture was placed into a reagent bottle for storage purposes. Before depositing the composite solution onto the glass slip, the glass coverslips must be cleaned using acetone solution to eliminate any fingerprint marks or dirt. Then, the glass slip was coated with a $50 \mathrm{~nm}$ gold layer using the sputter coater model K575X with $20 \mathrm{~mA}$ 
of current and $2.2 \mathrm{kV}$ of voltage. Eventually, another coating process was performed on the gold layer to accomplish the fabrication of the sensing thin film. Hence, the NCC/PEDOT solution was placed on the gold thin film and then spun for $30 \mathrm{~s}$ using the Spin Coating System, P-6708D, which operated at $3000 \mathrm{rpm}$, to ensure that a thin layer was coated and covered evenly on a gold film.

Continuing with the analyte, various concentrations of mercury ion were employed throughout the experiment. The deionized water and standard solution of mercury ion at a concentration of $1000 \mathrm{ppm}$ were involved in the preparation of various analyte concentrations. To produce the concentrations of $0.01,0.1,1$, and $10 \mathrm{ppm}$, the concentrated solution of mercury $\left(\mathrm{Hg}^{2+}\right)$ was diluted using the $\mathrm{M}_{1} \mathrm{~V}_{1}=\mathrm{M}_{2} \mathrm{~V}_{2}$ formula.

\subsection{Thin Film Characterization}

The characterizations began with the structural properties by Fourier transform infrared (FTIR). The spectra measurements of the composite material were performed using the FTIR spectrophotometer (Perkin-Elmer Spectrum 100, Waltham, MA, USA) within a range from 400 to $4000 \mathrm{~cm}^{-1}$. Then, the AFM images of the prepared thin films were examined by Bruker AFM (Multimode 8) in Scan Asyst mode, with scan sizes in a range of $1 \mu \mathrm{m} \times 1 \mu \mathrm{m}$. It will then proceed with the optical properties, where UV-vis spectroscopy (Shimadzu UV-3600) was utilized to measure the sample absorption spectra ranging from 220 to $700 \mathrm{~nm}$. The absorption peak obtained from the UV-vis spectrophotometer can also be applied to evaluate the optical band gap energy. Meanwhile, for the potential plasmonic sensing properties, SPR spectroscopy was set up as depicted in Figure 1. Using an index matching liquid, the sensing layer was coated onto the gold layer, which was sandwiched between the cell and the prism on the optical stage. Next, the varied concentrations of $\mathrm{Hg}^{2+}$ solutions were instilled into the cell one at a time by a microsyringe during the analysis, and the O-ring was used for the sensing thin film to make contact with the targeted analyte. The cell and prism were attached on a rotational stage (Newport MM3000) operated by a stepper motor with a resolution of $0.001^{\circ}$. An He-Ne laser, as a light source, passed through the pin hole, filter, optical chopper, and polarizer, in order to allow p-polarized monochromatic light with a specific wavelength to strike the prism [57-59]. The reflected light is then recorded and captured by the sensitive photodiode connected by a lock-in amplifier [60-62].

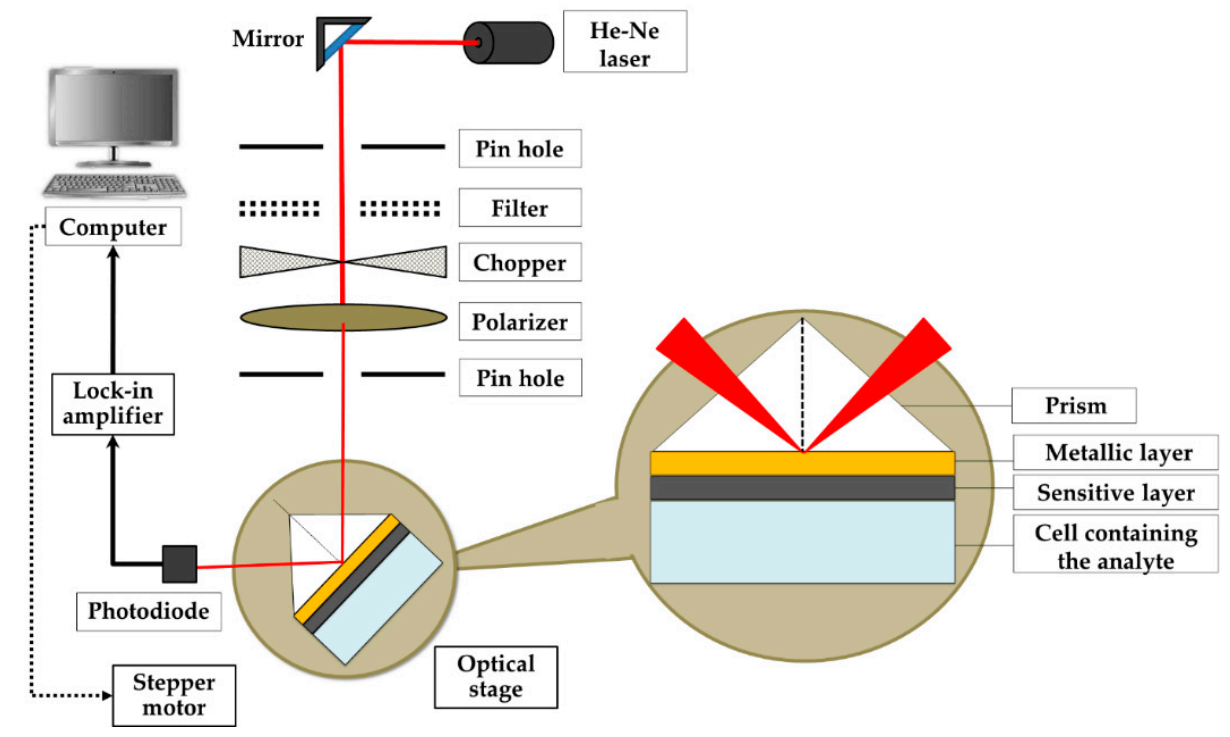

Figure 1. Experimental setup for exploring plasmonic sensing of the NCC/PEDOT thin film. 


\section{Results}

\subsection{Structural Properties}

Figure 2 shows the comparison of FTIR spectrum for NCC, PEDOT, and NCC/PEDOT with NCC as a base material. The FTIR spectra are recorded within wavenumbers ranging from 500 to $4000 \mathrm{~cm}^{-1}$. Based on the FTIR spectrum, the significant absorption peaks are assigned to identify the characteristics of the functional groups of each composite thin film.

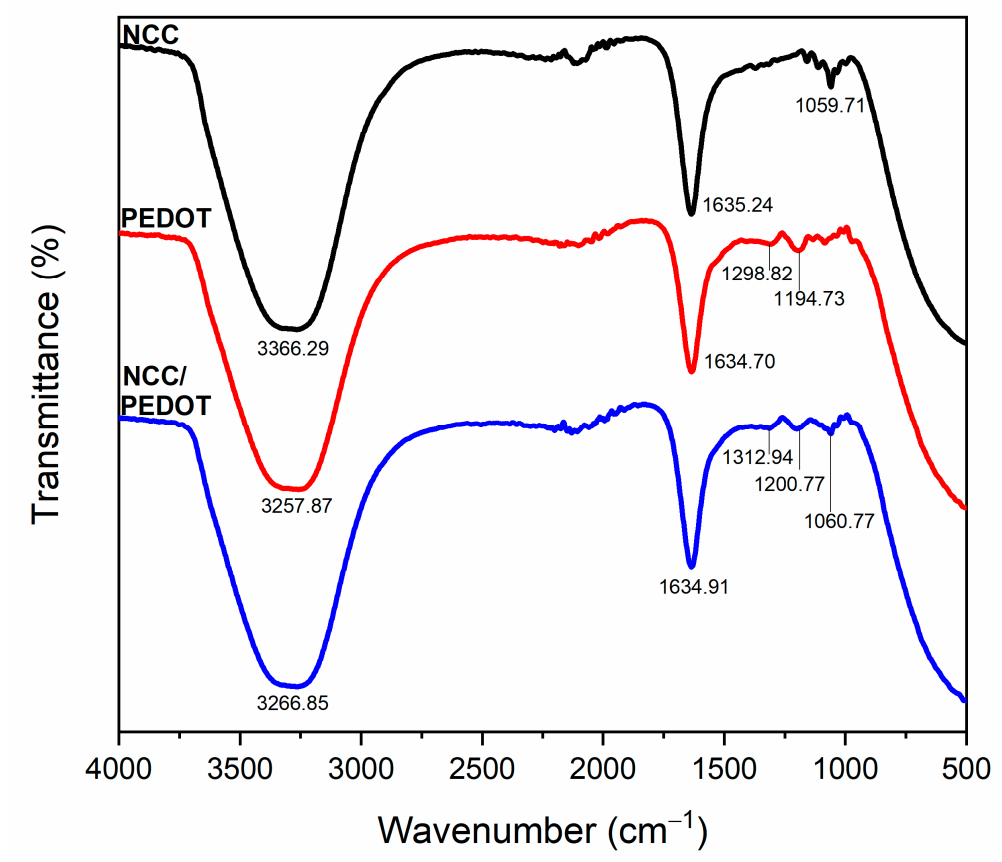

Figure 2. FTIR spectrum of NCC, PEDOT, and NCC/PEDOT thin film.

The FTIR spectrum of NCC thin film showed the characteristic peak of alcohol with $\mathrm{O}-\mathrm{H}$ stretching bonds representing $3366.29 \mathrm{~cm}^{-1}$. This characteristic peak is typically found in another previous study of NCC spectra [63]. The other peak at $1635.24 \mathrm{~cm}^{-1}$ represents the $\mathrm{O}-\mathrm{H}$ bending of absorbed water, while the peak at $1059.71 \mathrm{~cm}^{-1}$ corresponds to $\mathrm{C}-\mathrm{O}$ stretching bonds. Hence, this spectrum is in good agreement with previous studies of NCC $[64,65]$.

Next, in the spectra of PEDOT thin film, the broad absorption peak that appeared at $3257.87 \mathrm{~cm}^{-1}$ can be indicated to the $\mathrm{O}-\mathrm{H}$ stretching bond, which represents an alcohol group. Then, $\mathrm{C}=\mathrm{C}$ stretching bond at $1634.70 \mathrm{~cm}^{-1}$ is attributed to the quinoidal structure of PEDOT [66]. Meanwhile, two peaks at $1298.82 \mathrm{~cm}^{-1}$ and $1194.73 \mathrm{~cm}^{-1}$ have explained the presence of ethylenedioxy and sulfonate groups in the PEDOT surface [67].

The spectrum of NCC/PEDOT and PEDOT thin film has displayed a few common properties, which the absorption bands at $3266.85 \mathrm{~cm}^{-1}$ referred to as $\mathrm{O}-\mathrm{H}$ stretching vibration. Besides the absorption band displayed at $1634.91 \mathrm{~cm}^{-1}$ assigned to $\mathrm{O}-\mathrm{H}$ bending of absorbed water, there are also characteristic absorbance bands centered at $1312.94 \mathrm{~cm}^{-1}$ and $1200.77 \mathrm{~cm}^{-1}$, which correspond to sulfonate and ether groups, respectively. Lastly, the $\mathrm{C}-\mathrm{O}$ stretching bond is located at $1060.07 \mathrm{~cm}^{-1}$. The functional groups that exist match the spectra of the NCC/PEDOT thin film in a previous study by Ravit et al. (2019) [68].

The comparison of FTIR spectra of the NCC, PEDOT, and NCC/PEDOT thin film proved the combination band of NCC and PEDOT. In general, the peak around 3200 to 3400 $\mathrm{cm}^{-1}$ is assigned to the $\mathrm{O}-\mathrm{H}$ group. Then, the $\mathrm{O}-\mathrm{H}$ bending of absorbed water is located at around $1630 \mathrm{~cm}^{-1}$. Meanwhile, ether and sulfonate groups only existed in PEDOT and NCC/PEDOT spectra. 


\subsection{Surface Morphology}

The morphology features of the spin-coated NCC, PEDOT, and NCC/PEDOT thin films were identified by atomic force microscope (AFM), and it was carried out in tapping mode. In this study, a scan size was fixed $(1 \mu \mathrm{m} \times 1 \mu \mathrm{m})$, for the imaging of the topographical difference in the thin films. From AFM images, the root mean square (RMS) roughness was obtained, which indicates the relative roughness and the standard deviation of the surface height. Figures $3 a-c$ and $4 a-c$ show the AFM images of the NCC, PEDOT, and NCC/PEDOT thin film, respectively. Then, the AFM results of NCC/PEDOT thin film after being in contact with the $\mathrm{Hg}^{2+}$ solution are depicted in Figures $3 \mathrm{~d}$ and $4 \mathrm{~d}$.

Based on the two-dimensional (2D) and three-dimensional (3D) images of the NCC, PEDOT, and NCC/PEDOT thin film, it can be observed that the composite materials are well distributed on the whole scanned surface, the gold thin film. In Figure 3a, the images of NCC thin films show a rod-like structure with an RMS value of $2.90 \mathrm{~nm}$. This morphology was related to another study done by Elazzouzi-Hafraoui et al. (2008) and the rod structure could be attributed to the crystallinity properties of NCC [69]. On the other hand, a sharp and relatively rough surface with RMS roughness of $2.79 \mathrm{~nm}$ for the PEDOT thin film was obtained. Then, from Figure 3c, it can be observed that, with the presence of NCC on the sensor surface, the rod-like shape reappeared in the NCC/PEDOT thin film, which leads to agglomeration. The incorporation between NCC and PEDOT results in the surface roughness increasing to $8.32 \mathrm{~nm}$.
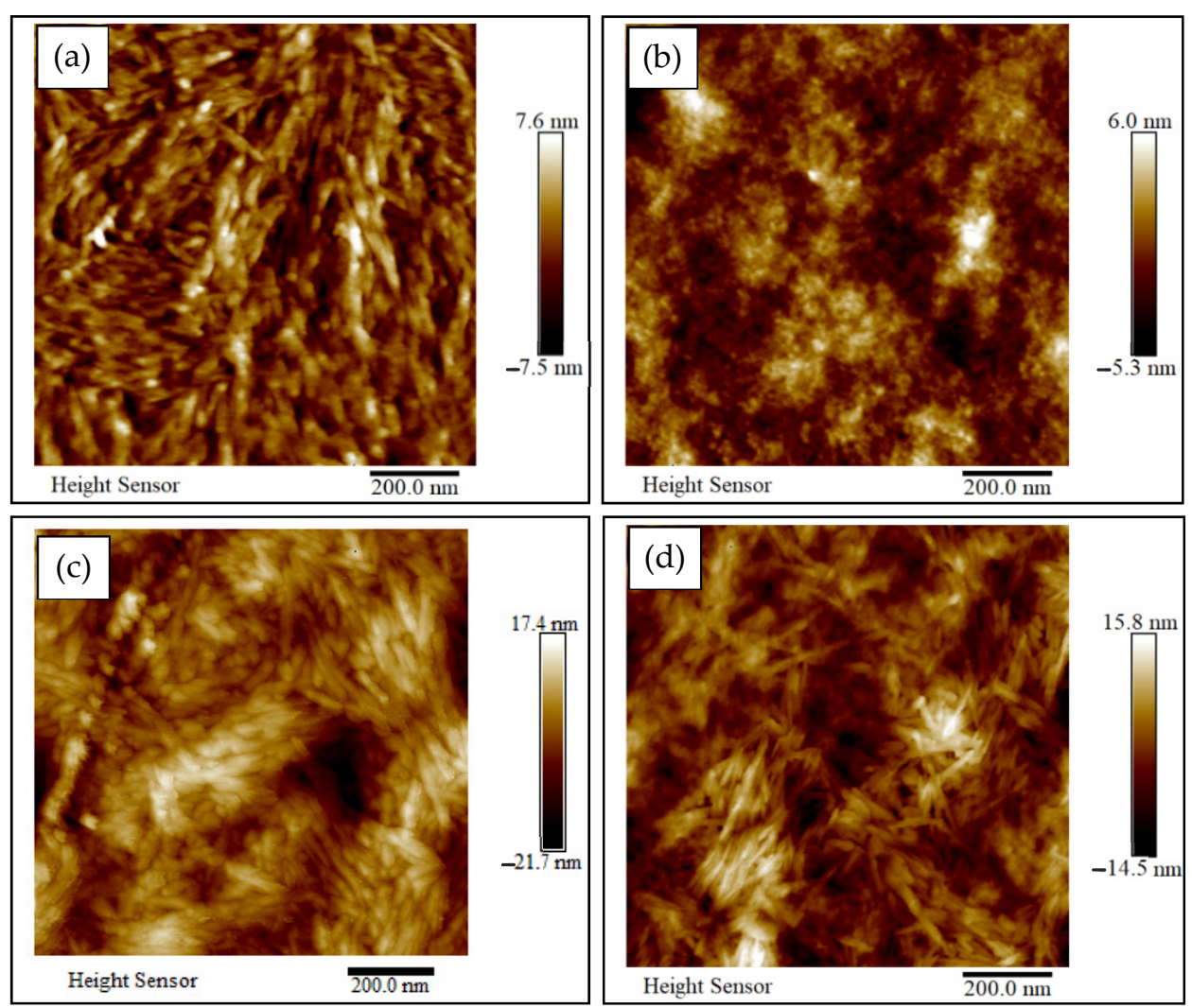

Figure 3. AFM topographic images in 2D of (a) NCC, (b) PEDOT, (c) NCC/PEDOT (before), and (d) NCC/PEDOT (after) thin films. 

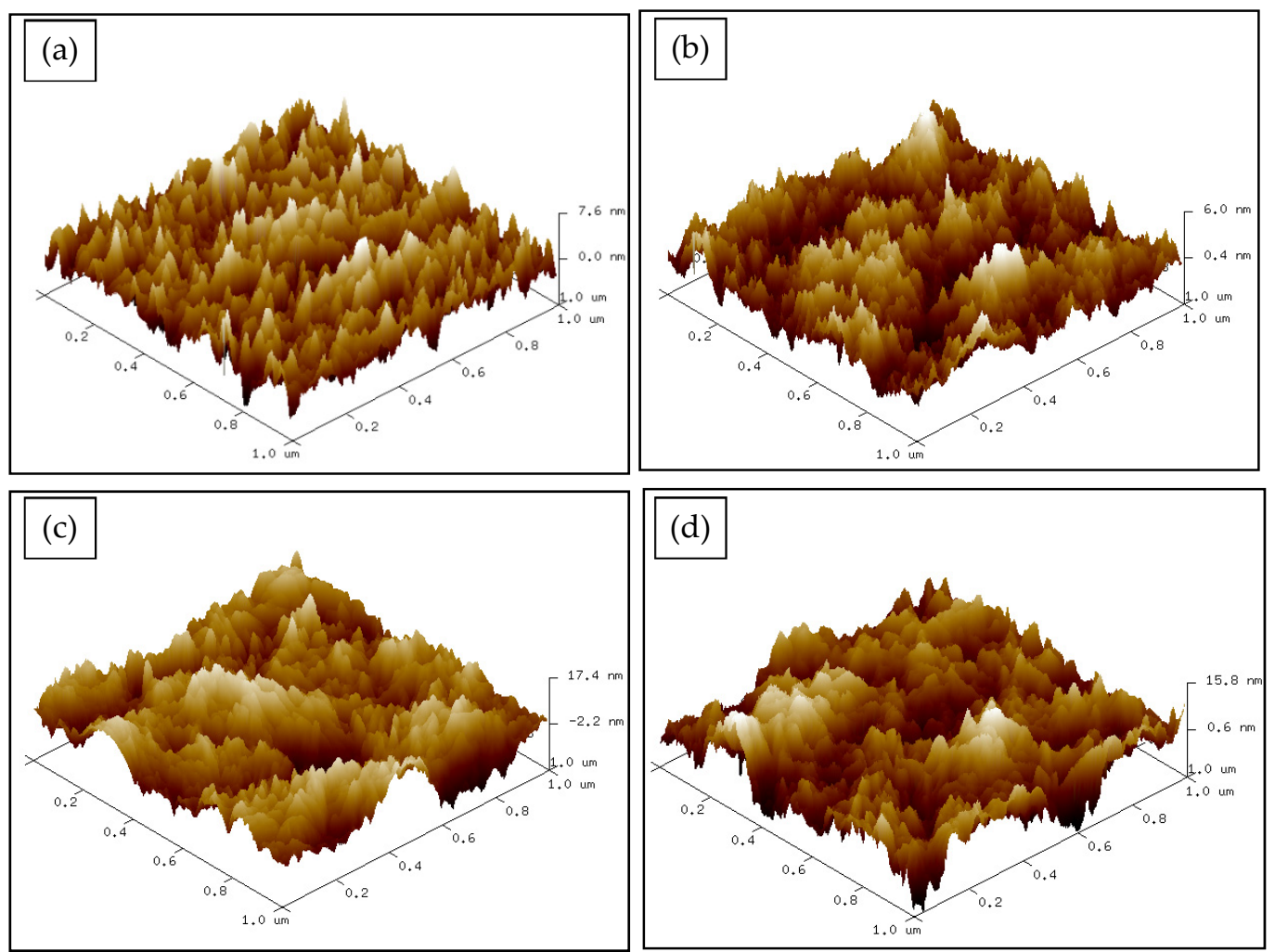

Figure 4. AFM topographic images in 3D of (a) NCC, (b) PEDOT, (c) NCC/PEDOT (before), and (d) NCC/PEDOT (after) thin films.

\subsection{Optical Properties}

To identify the optical properties of composite materials, the absorption spectra of the NCC, PEDOT, and NCC/PEDOT thin film were recorded at different wavelengths, ranging from $220 \mathrm{~nm}$ to $700 \mathrm{~nm}$. The UV/vis absorption spectrum of three composite thin films is presented in Figure 5.

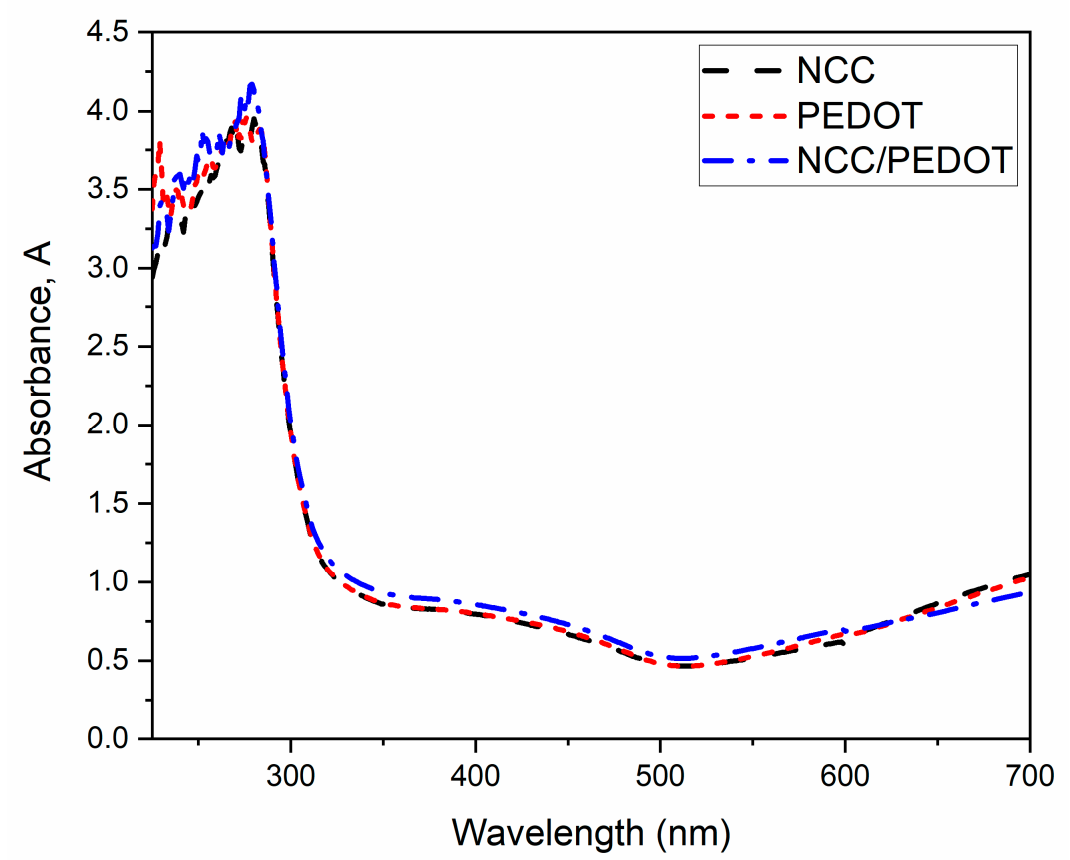

Figure 5. Absorbance spectrum of the NCC, PEDOT, and NCC/PEDOT thin film. 
As shown in the figure, there is a distinction in the absorbance value for the absorption spectrum of each thin film. The spectra for NCC show the highest absorbance value of 3.90 at $268 \mathrm{~nm}$ and $280 \mathrm{~nm}$, whereas the absorption band is around $260 \mathrm{~nm}$ to $280 \mathrm{~nm}$. Then, PEDOT also shows the same value of highest absorbance as NCC at $269 \mathrm{~nm}$, which can be assigned to the substituted phenyl groups of PEDOT [70]. Meanwhile, the NCC/PEDOT thin film exhibits the highest absorbance value among the others, of approximately 4.19 at the wavelength of $279 \mathrm{~nm}$. Meanwhile, from the absorption spectra of UV/vis analysis, the relationship between the absorption coefficient and the energy of a photon can be studied via the Tauc equation, as expressed in the following equation [71]:

$$
\alpha=\frac{k\left(h v-E_{g}\right)^{\frac{1}{2}}}{h v}
$$

Further, it can be rearranged into

$$
(\alpha h v)^{2}=k\left(h v-E_{g}\right),
$$

where $\alpha$ is the absorption coefficient, $h v$ is the energy of a photon, $k$ is a proportionality constant, and $E_{g}$ is the optical band gap. Then, an intersection from extrapolation of the plot of $(\alpha h v)^{2}$ against $h v$ will determine the optical energy band gap of the NCC, PEDOT, and NCC/PEDOT thin film, as illustrated in Figures 6-8, respectively [72]. Thus, the achieved values of the optical band gap, $E_{g}$, were obtained from the extrapolation of the straight plot on the $x$-axis from Tauc's relation.

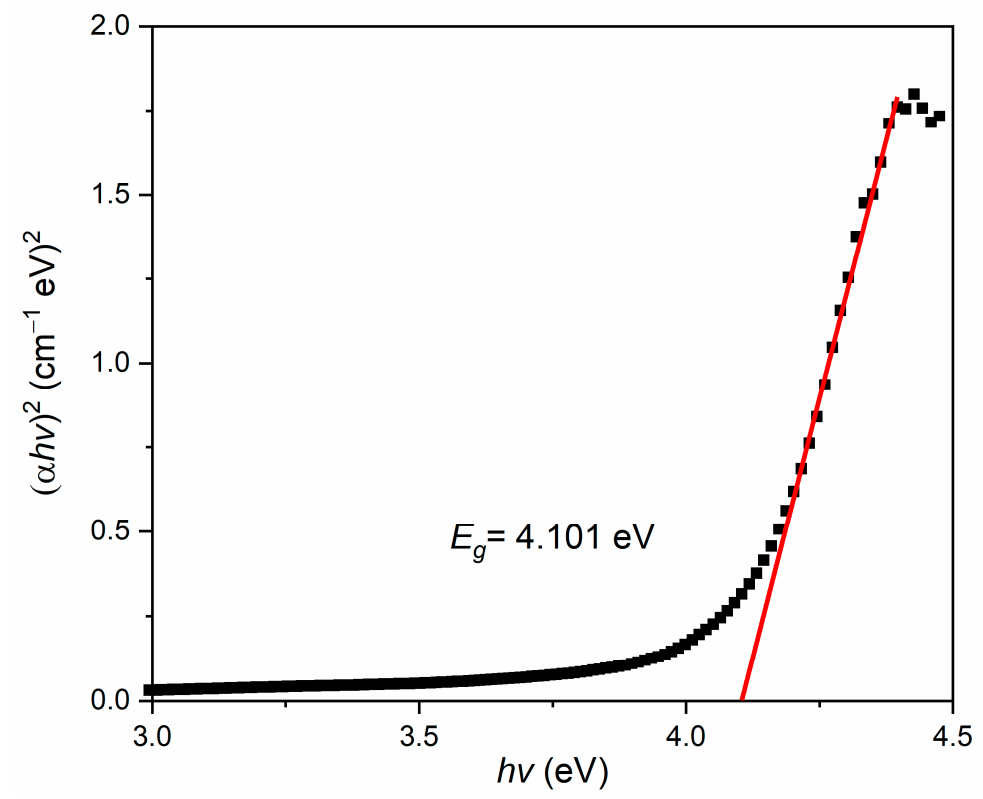

Figure 6. Energy band gap of the NCC thin film. 


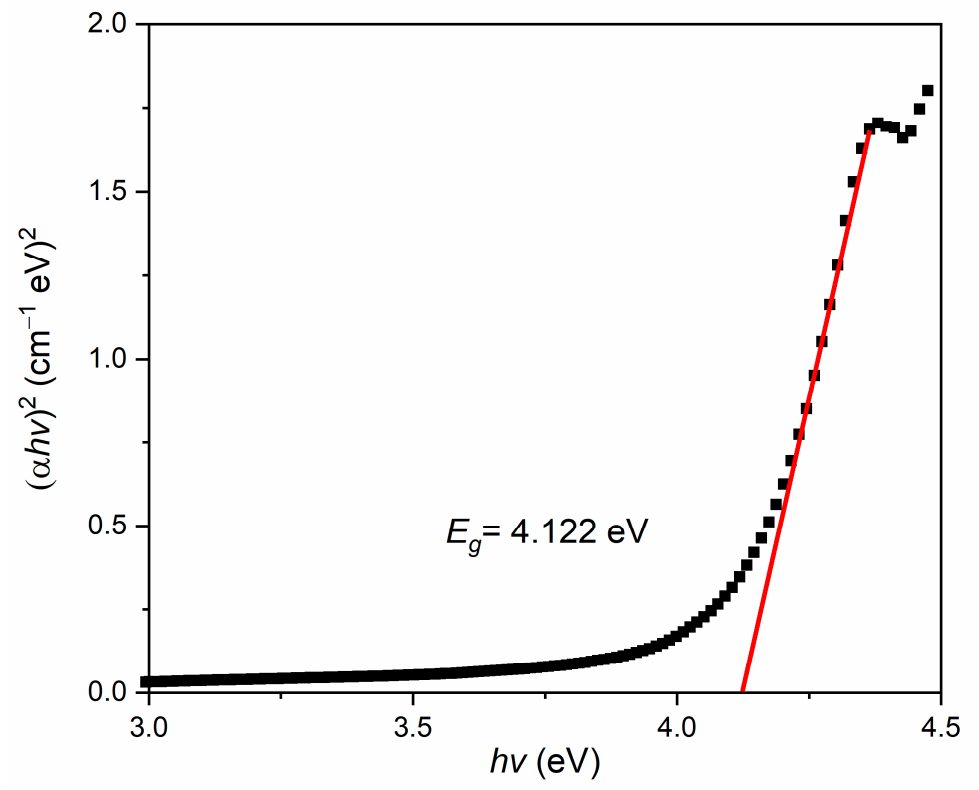

Figure 7. Energy band gap of the PEDOT thin film.

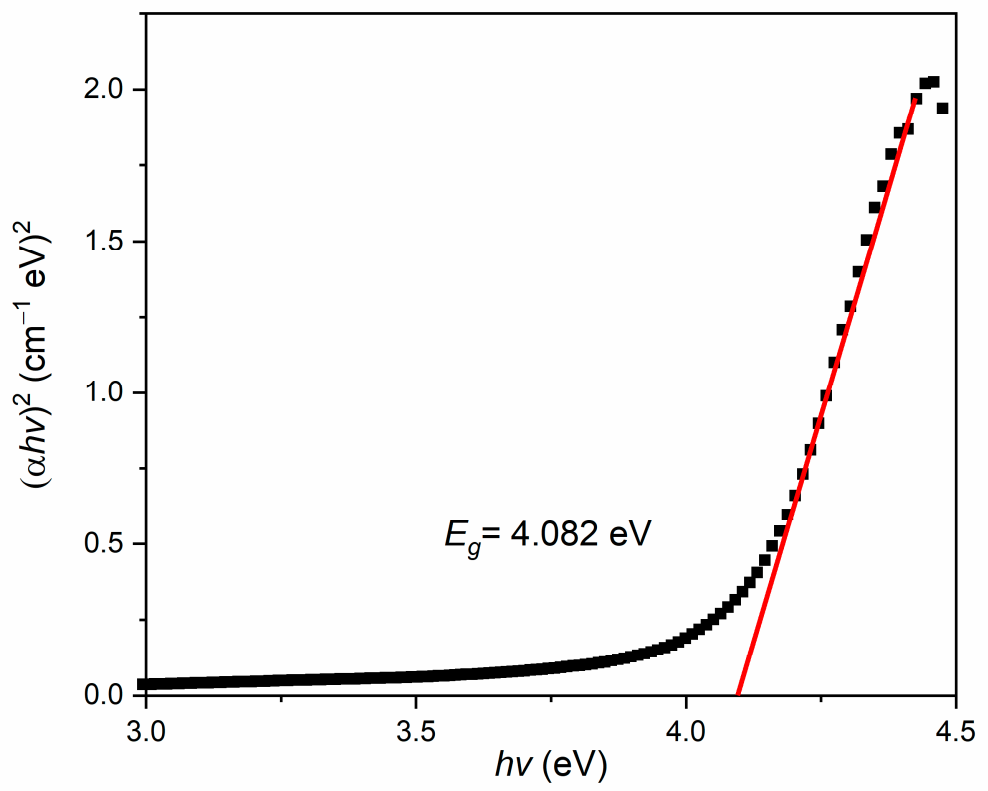

Figure 8. Energy band gap of the NCC/PEDOT thin film.

From Figures 6-8, the energy band gaps were experimentally obtained and plotted using linear fitting techniques. The plot of $(\alpha h v)^{2}$ versus $h v$ for NCC, PEDOT, and NCC/PEDOT displayed a slight difference in the value of the energy band gap, $E_{g}$, whereas PEDOT exhibit the highest optical band gap among all three thin films at $4.122 \mathrm{eV}$. Next, the energy band gap for the NCC thin film was found to be $4.101 \mathrm{eV}$, and the mixture of NCC and PEDOT produced a slight decrease in the band gap to $4.082 \mathrm{eV}$.

\subsection{Potential Plasmonic Sensing Properties}

The plasmonic sensing of the NCC/PEDOT thin film was investigated and tested with deionized water and various concentrations of analyte $(0.001 \mathrm{ppm}, 0.01 \mathrm{ppm}$, and $0.1 \mathrm{ppm}$ of $\mathrm{Hg}^{2+}$ ) via SPR. When the analyte was injected separately into the cell, the graph of reflectance against the incidence angle for each concentration was recorded and compared with deionized water $(0 \mathrm{ppm})$ as the baseline. This SPR-based plasmonic sensor works by 
monitoring the shift in the resonance angle, which can be influenced by any changes in the refractive index of the sensing layer attached to the gold thin film [73-75]. Figure 9 reveals a clear trend of an increase in the resonance angle shift of the NCC/PEDOT thin film in contact with $0 \mathrm{ppm}$ to $0.1 \mathrm{ppm}$ of mercury ion. This sensor is very sensitive to any changes near the metal surface. The attachment of metal ions on the layer of the NCC/PEDOT thin film appears to have contributed to the changes in the refractive index as well as the resonance angle [76-79]. The SPR signals were shifted to a higher incidence angle from $54.0099^{\circ}, 54.3782^{\circ}$, and $54.4086^{\circ}$ for $0.001 \mathrm{ppm}, 0.01 \mathrm{ppm}$, and $0.1 \mathrm{ppm}$ respectively. Because there is an interaction between the NCC/PEDOT thin film and the analyte, the existence of more active sites on the surface of the thin film may lead more mercury ions to occupy and access these sites [80].

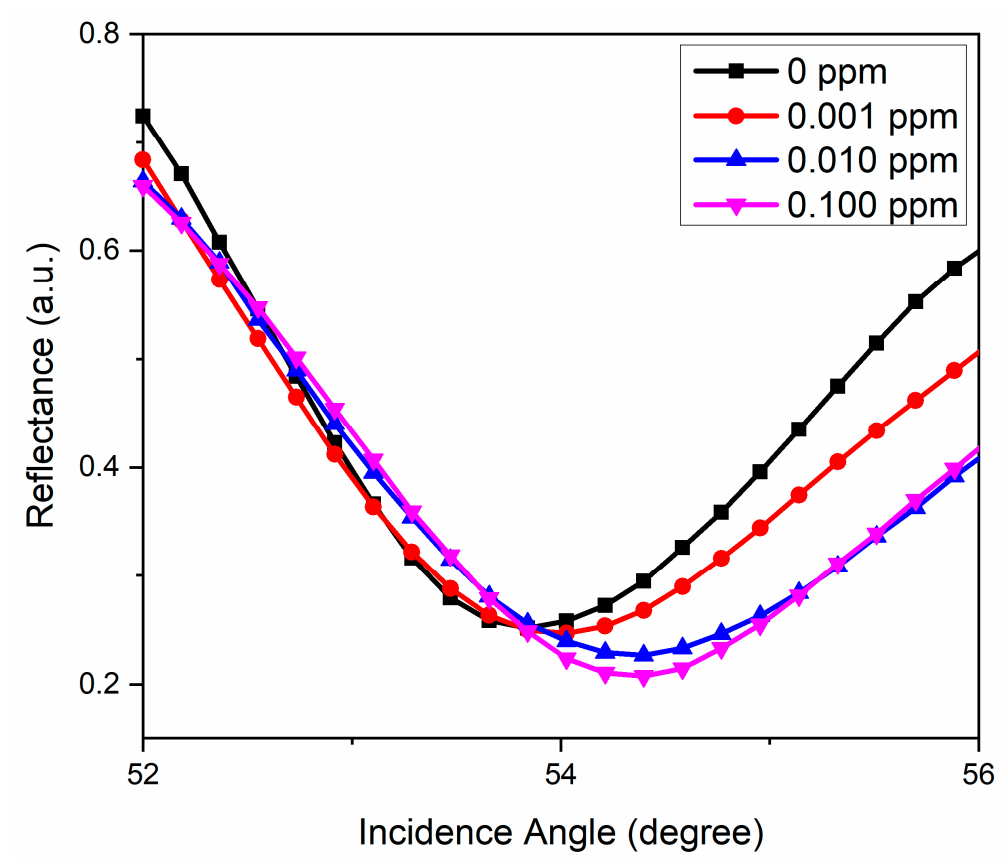

Figure 9. Reflectance as a function of the incidence angle for deionized water and various concentrations of mercury ion solution.

\section{Discussions}

In the characterization process, the structural and optical properties were observed based on three different thin films, NCC, PEDOT, and NCC/PEDOT. From the FTIR spectra, it is noticed that the functional groups of the NCC/PEDOT thin film have resulted in the incorporation between the biopolymer and conducting polymer solution. The presence of a $\mathrm{C}-\mathrm{O}$ stretching band of alcohol in the NCC thin film reoccurred in the spectra of $\mathrm{NCC} / \mathrm{PEDOT}$. Moreover, the absorption peak of the $\mathrm{S}=\mathrm{O}$ stretching band and $\mathrm{C}-\mathrm{O}-\mathrm{C}$ bond, marked at 1312.94 and $1200.77 \mathrm{~cm}^{-1}$, clearly indicates the formation of two main functional groups of conducting polymers in the composite solution [81,82]. Thus, overall characteristic peaks exist in the NCC/PEDOT thin film, corresponding to the identical functional groups in both spectra of NCC and PEDOT.

Meanwhile, the NCC/PEDOT thin film was observed before and after contact with the analyte solution. The morphology surface of the NCC/PEDOT thin film prepared by the spin-coating technique showed a significant change after being in contact with mercury ions. This revealed a similar thin rod-like structure as the thin film before being exposed to the analyte solution. Despite that, there are changes in surface roughness where the value decreased from $8.32 \mathrm{~nm}$ to $6.88 \mathrm{~nm}$. This indicated that the changes are probably affected by the formation of a pair of shared electrons between the thin film and the mercury solution. Anyway, the surface roughness of the thin film does not have any significant effect on 
the plasmonic performance, as the rough surfaces less than $20 \mathrm{~nm}$ do not influence the excitation of propagating surface plasmon along the metal surface [83].

Based on the absorption spectrum of three thin films, the results pointed out that the NCC/PEDOT thin film has the lowest optical band gap compared with the other two films. The results showed that a slight decrement in the energy band gap may be caused by the highest occupied molecular orbital (HOMO)-lowest unoccupied molecular orbital (LUMO) gap interaction. There is an interaction between two opposite surface charges carried by the NCC and PEDOT/PSS solution; therefore, this will influence the excitation of the electrons to be promoted from the valence band to the conduction band [84]. Hence, the incorporation process of the NCC and PEDOT solution reduces the band gap between the HOMO and LUMO band. The changes in the energy band gap of the thin films can also be attributed to the recrystallization of atoms in the crystal lattice when there is an addition of NCC into the composite material [85]. Then, the conducting properties of PEDOT/PSS are also believed effect to this outcome.

Importantly, the sensing potential of the NCC/PEDOT thin film toward mercury ions was observed by the changes in the resonance angle. As the concentrations increased, the reflectance curves were increased and shifted to the right. The deposited sensing layer on the gold thin film plays an important role in detecting the analyte. When the mercury ions are attached to the sensing layer, the analyte may interact with the NCC/PEDOT thin film owing to the formation of a pair of shared electrons between the positive charge from the mercury ion and the negative charge from the PEDOT. Thus, the NCC/PEDOT thin film showed a response in detecting mercury ions using surface plasmon resonance spectroscopy. Based on the response, the sensitivity of the sensors can also be evaluated by plotting a graph of resonance angle shift against concentration, and the slope of the linear regression plotting will define the sensitivity value [86-89]. In future work, it would be interesting to identify the sensitivity of other heavy metal ions as compared with mercury ions. The selectivity of the sensor towards mercury ion in the presence of various heavy metal ions could also be an interesting future study.

\section{Conclusions}

In a nutshell, the structural and optical properties of the nanocrystalline cellulose/poly (3,4-ethylenethiophene) (NCC/PEDOT) sensing thin film were synthesized and studied. Furthermore, the thin film was developed as an SPR sensing layer for the detection of mercury ions in an aqueous solution. Analysis from the characterization techniques of the prepared thin films by FTIR, AFM, and UV/vis showed the presence of functional groups in the composite materials, followed by the surface morphology and the rough mean standard of the NCC/PEDOT thin film after being in contact with mercury ions, which confirmed the interaction between the thin films and the analyte. The absorption peaks of UV/vis spectra reveal that the NCC/PEDOT thin film exhibits the lowest energy band gap and the PEDOT thin film has the highest value. As the main objective, the detection of mercury ions using the NCC/PEDOT thin film indicated a positive response according to the reflectance curves of the thin film in contact with various concentrations of mercury ions. Besides, this paper is the first report on the incorporation between two types of polymers, nanocrystalline cellulose and poly(3,4-ethylenethiophene), to detect heavy metal ions using an optical sensor. This study has extended the opportunity of developing biopolymers and conducting polymer-based materials as a sensing layer in sensor applications.

Author Contributions: Conceptualization, N.S.M.R.; methodology, N.A.S.O.; validation, Y.W.F.; formal analysis, N.A.A.A.; investigation, N.S.M.R.; resources, J.Y.C.L.; writing-original draft preparation, N.S.M.R.; writing-review and editing, Y.W.F.; visualization, W.M.E.M.M.D. and N.I.M.F.; supervision, Y.W.F. and J.Y.C.L.; funding acquisition, Y.W.F. All authors have read and agreed to the published version of the manuscript. 
Funding: This research was financially supported by the Ministry of Higher Education, Malaysia, grant number FRGS/1/2019/STG02/UPM/02/1 and Putra Grant Universiti Putra Malaysia.

Institutional Review Board statement: Not applicable.

Informed Consent Statement: Not applicable.

Data Availability Statement: Data sharing is not applicable in this article.

Acknowledgments: The authors also acknowledged the laboratory facilities provided by the Department of Physics, Department of Chemistry and Functional Devices Laboratory, Universiti Putra Malaysia.

Conflicts of Interest: The authors declare no conflict of interest.

\section{References}

1. Tang, F.A.N.; Zhang, L.; Zhang, Z.; Cheng, Z.; Zhu, X. Cellulose filter paper with antibacterial activity from surface-Initiated ATRP. J. Macromol. Sci. 2009, 46, 989-996. [CrossRef]

2. Incani, V.; Danumah, C.; Boluk, Y. Nanocomposites of nanocrystalline cellulose for enzyme immobilization. Cellulose 2013, 20, 191-200. [CrossRef]

3. Edwards, J.V.; Prevost, N.; French, A.; Concha, M.; DeLucca, A.; Wu, Q. Nanocellulose-based biosensors: Design, preparation, and activity of peptide-linked cotton cellulose nanocrystals having fluorimetric and colorimetric elastase detection sensitivity. Engineering 2013, 5, 20-28. [CrossRef]

4. Rånby, B.G. The colloidal properties of cellulose micelles. Discuss. Faraday Soc. 1951, 11, 158-164. [CrossRef]

5. Habibi, Y.; Lucia, L.A.; Rojas, O.J. Cellulose nanocrystals: Chemistry, self-assembly, and applications. Chem. Rev. 2010, 110, 3479-3500. [CrossRef]

6. You, J.; Hu, H.; Zhou, J.; Zhang, L.; Zhang, Y.; Kondo, T. Novel cellulose polyampholyte-gold nanoparticle-based colorimetric competition assay for the detection of cysteine and mercury(II). Langmuir 2013, 29, 5085-5092. [CrossRef] [PubMed]

7. Manan, F.A.A.; Weng, W.; Abdullah, J.; Yusof, N.A.; Ahmad, I. Nanocrystalline cellulose decorated quantum dots based tyrosinase biosensor for phenol determination. Mater. Sci. Eng. C 2019, 99, 37-46. [CrossRef]

8. Chen, S.; Tao, H.; Wang, Y.; Ma, Z. Process optimization of soy protein isolate-based edible films containing nanocrystalline cellulose from sunflower seed hull and chitosan. Trans. Chin. Soc. Agric. Eng. 2016, 32, 306-314.

9. Tan, C.; Peng, J.; Lin, W.; Xing, Y.; Xu, K.; Wu, J.; Chen, M. Role of surface modification and mechanical orientation on property enhancement of cellulose nanocrystals/polymer nanocomposites. Eur. Polym. J. 2015, 62, 186-197. [CrossRef]

10. Golmohammadi, H.; Morales-Narváez, E.; Naghdi, T.; Merkoçi, A. Nanocellulose in sensing and biosensing. Chem. Mater. 2017, 29, 5426-5446. [CrossRef]

11. Listyanda, R.F.; Kusmono; Wildan, M.W.; Ilman, M.N. Extraction and characterization of nanocrystalline cellulose (NCC) from ramie fiber by hydrochloric acid hydrolysis. AIP Conf. Proc. 2020, 2217, 030069.

12. Jia, Y.; Guo, Y.; Wang, S.; Chen, W.; Zhang, J.; Zheng, W.; Jiang, X. Nanocrystalline cellulose mediated seed-growth for ultra-robust colorimetric detection of hydrogen sulfide. Nanoscale 2017, 9, 9811-9817. [CrossRef]

13. Heidari, H.; Karbalaee, M. Ultrasonic assisted synthesis of nanocrystalline cellulose as support and reducing agent for Ag nanoparticles: Green synthesis and novel effective nanocatalyst for degradation of organic dyes. Appl. Organomet. Chem. 2019, 33, e5070. [CrossRef]

14. Chen, Q.; Shi, Y.; Chen, G.; Cai, M. Enhanced mechanical and hydrophobic properties of composite cassava starch films with stearic acid modified MCC (microcrystalline cellulose)/NCC (nanocellulose) as strength agent. Int. J. Biol. Macromol. 2020, 142, 846-854. [CrossRef]

15. Daniyal, W.M.E.M.M.; Fen, Y.W.; Abdullah, J.; Saleviter, S.; Sheh Omar, N.A. Preparation and characterization of hexadecyltrimethylammonium bromide modified nanocrystalline cellulose/graphene oxide composite thin film and its potential in sensing copper ion using surface plasmon resonance technique. Optik 2018, 173, 71-77. [CrossRef]

16. Omar, N.A.S.; Fen, Y.W.; Ramli, I.; Azmi, U.Z.M.; Hashim, H.S.; Abdullah, J.; Mahdi, M.A. Cellulose and vanadium plasmonic sensor to measure $\mathrm{Ni}^{2+}$ ions. Appl. Sci. 2021, 11, 2963. [CrossRef]

17. Cui, X.; Martin, D.C. Electrochemical deposition and characterization of poly(3,4-ethylenedioxythiophene) on neural microelectrode arrays. Sens. Actuators B 2003, 89, 92-102. [CrossRef]

18. Yang, Y.; Jiang, Y.; Xu, J.; Yu, J. Conducting PEDOT-PSS composite films assembled by LB technique. Colloids Surf. A Physicochem. Eng. Asp. 2007, 302, 157-161. [CrossRef]

19. Harman, D.; Gorkin, R.; Stevens, L.; Thompson, B.; Wagner, K. Poly(3,4-ethylenedioxythiophene): Dextran sulfate (PEDOT: DS)-A highly processable conductive organic biopolymer. Acta Biomater. 2015, 14, 33-42. [CrossRef] [PubMed]

20. Cao, Z.; Chen, Z.; Escoubas, L. Optical, structural, and electrical properties of PEDOT:PSS thin films doped with silver nanoprisms. Opt. Mater. Express 2014, 4, 2525. [CrossRef]

21. Janmanee, R.; Chuekachang, S.; Sriwichai, S.; Baba, A.; Phanichphant, S. Functional conducting polymers in the application of SPR biosensors. J. Nanotechnol. 2012, 2012, 1-7. [CrossRef] 
22. Zhao, Q.; Jamal, R.; Zhang, L.; Wang, M.; Abdiryim, T. The structure and properties of PEDOT synthesized by template-free solution method. Nanoscale Res. Lett. 2014, 9, 557. [CrossRef] [PubMed]

23. Pacios, R.; Marcilla, R.; Pozo-gonzalo, C.; Pomposo, J.A.; Grande, H.; Aizpurua, J.; Mecerreyes, D. Combined electrochromic and plasmonic optical responses in conducting polymer/metal nanoparticle films. J. Nanosci. Nanotechnol. 2007, 7, $2938-2941$. [CrossRef]

24. Yemata, T.A.; Zheng, Y.; Kyaw, A.K.K.; Wang, X.; Song, J.; Chin, W.S.; Xu, J. Modulation of the doping level of PEDOT:PSS film by treatment with hydrazine to improve the Seebeck coefficient. R. Soc. Chem. 2020, 10, 1786-1792. [CrossRef]

25. McFarlane, S.L.; Deore, B.A.; Svenda, N.; Freund, M.S. A one-step, organic-solvent processable synthesis of PEDOT thin films via in situ metastable chemical polymerization. Macromolecules 2010, 43, 10241-10245. [CrossRef]

26. Horikawa, M.; Fujiki, T.; Shirosaki, T.; Ryu, N.; Sakurai, H.; Nagaoka, S.; Ihara, H. The development of a highly conductive PEDOT system by doping with partially crystalline sulfated cellulose and its electric conductivity. J. Mater. Chem. C 2015, 3, 8881-8887. [CrossRef]

27. Sui, L.; Zhang, B.; Wang, J.; Cai, A. Polymerization of PEDOT/PSS/Chitosan-coated electrodes for electrochemical bio-sensing. Coatings 2017, 7, 96. [CrossRef]

28. Gangopadhyay, R.; Das, B.; Molla, M.R. How does PEDOT combine with PSS? Insights from structural studies. RSC Adv. 2014, 4, 43912-43920. [CrossRef]

29. Najeeb, M.A.; Abdullah, S.M.; Aziz, F.; Ahmad, Z.; Rafique, S.; Wageh, S.; Al-Ghamdi, A.A.; Sulaiman, K.; Touati, F.; Shakoor, R.A.; et al. Structural, morphological and optical properties of PEDOT:PSS/QDs nano-composite films prepared by spin-casting. Phys. E 2016, 83, 64-68. [CrossRef]

30. Rattan, S.; Singhal, P.; Verma, A.L. Synthesis of PEDOT: PSS (Poly(3,4-ethylenedioxythiophene)/poly(4-styrene sulfonate))/NGPs (nanographitic platelets) nanocomposites as chemiresistive Sensors for detection of nitroaromatics. Polym. Eng. Sci. 2013, 53, 2045-2052. [CrossRef]

31. Wang, H.; Xu, C.; Yuan, B. Polymer-based electrochemical sensing platform for heavy metal ions detection-A critical review. Int. J. Electrochem. Sci. 2019, 14, 8760-8771. [CrossRef]

32. Ravit, R.; Abdullah, J.; Ahmad, I.; Sulaiman, Y. Electrochemical performance of poly(3,4-ethylenedioxythipohene)/nanocrystalline cellulose (PEDOT/NCC) film for supercapacitor. Carbohydr. Polym. 2019, 203, 128-138. [CrossRef] [PubMed]

33. Chauhan, K.; Singh, P.; Singhal, R.K. New Chitosan-Thiomer: An efficient colorimetric sensor and effective sorbent for mercury at ultralow concentration. ACS Appl. Mater. Interfaces 2015, 7, 26069-26078. [CrossRef]

34. Kumar, P.; Kim, K.; Bansal, V.; Lazarides, T.; Kumar, N. Progress in the sensing techniques for heavy metal ions using nanomaterials. J. Ind. Eng. Chem. 2017, 54, 30-43. [CrossRef]

35. Palermo, G.; Sreekanth, K.V.; Maccaferri, N.; Lio, G.E.; Nicoletta, G.; De Angelis, F.; Hinczewski, M.; Strangi, G. Hyperbolic dispersion metasurfaces for molecular biosensing. Nanophotonics 2020, 10, 295-314. [CrossRef]

36. Palermo, G.; Rippa, M.; Conti, Y.; Vestri, A.; Castagna, R.; Fusco, G.; Suffredini, E.; Zhou, J.; Zyss, J.; De Luca, A.; et al. Plasmonic metasurfaces based on pyramidal nanoholes for high-efficiency SERS biosensing. ACS Appl. Mater. Interfaces 2021, 13, 43715-43725. [CrossRef] [PubMed]

37. Lukosz, W.; Tiefenthaler, K. Embossing technique for fabricating integrated optical components in hard inorganic waveguiding materials. Opt. Lett. 1983, 8, 537-539. [CrossRef]

38. Cai, S.; Pan, H.; González-Vila, Á.; Guo, T.; Gillan, D.C.; Wattiez, R.; Caucheteur, C. Selective detection of cadmium ions using plasmonic optical fiber gratings functionalized with bacteria. Opt. Express 2020, 28, 19740-19749. [CrossRef]

39. Verma, R.; Gupta, B.D. Detection of heavy metal ions in contaminated water by surface plasmon resonance based optical fibre sensor using conducting polymer and chitosan. Food Chem. 2015, 166, 568-575. [CrossRef]

40. Homola, J.; Ctyroky, J.; Slavik, R.; Skalsky, M. Surface plasmon resonance sensors using optical waveguides. In Proceedings of the Third Conference on Photonic Systems for Ecological Monitoring, Prague, Czech Republic, 11 August 1997; pp. 100-106.

41. Eddin, F.B.K.; Fen, Y.W.; Omar, N.A.S.; Liew, J.Y.C.; Daniyal, W.M.E.M.M. Femtomolar detection of dopamine using surface plasmon resonance sensor based on chitosan/graphene quantum dots thin film. Spectrochim. Acta-Part A Mol. Biomol. Spectrosc. 2021, 263, 120202. [CrossRef]

42. Daniyal, W.M.E.M.M.; Fen, Y.W.; Abdullah, J.; Sadrolhosseini, A.R.; Mahdi, M.A. Design and optimization of surface plasmon resonance spectroscopy for optical constant characterization and potential sensing application: Theoretical and experimental approaches. Photonics 2021, 8, 361. [CrossRef]

43. Omar, N.A.S.; Fen, Y.W.; Abdullah, J.; Sadrolhosseini, A.R.; Kamil, Y.M.; Fauzi, N.I.M.; Hashim, H.S.; Mahdi, M.A. Quantitative and selective surface plasmon resonance response based on a reduced graphene oxide-polyamidoamine nanocomposite for detection of dengue virus E-proteins. Nanomaterials 2020, 10, 569. [CrossRef] [PubMed]

44. Omar, N.A.S.; Fen, Y.W.; Abdullah, J.; Mustapha Kamil, Y.; Daniyal, W.M.E.M.M.; Sadrolhosseini, A.R.; Mahdi, M.A. Sensitive detection of dengue virus type 2 E-Proteins signals using self-assembled monolayers/reduced graphene oxide-PAMAM dendrimer thin film-SPR optical sensor. Sci. Rep. 2020, 10, 2374. [CrossRef] [PubMed]

45. Omar, N.A.S.; Fen, Y.W.; Ramli, I.; Sadrolhosseini, A.R.; Abdullah, J.; Yusof, N.A.; Kamil, Y.M.; Mahdi, M.A. An optical sensor for dengue envelope proteins using polyamidoamine dendrimer biopolymer-based nanocomposite thin film: Enhanced sensitivity, selectivity, and recovery studies. Polymers 2021, 13, 762. [CrossRef] [PubMed] 
46. Rosddi, N.N.M.; Fen, Y.W.; Anas, N.A.A.; Omar, N.A.S.; Ramdzan, N.S.M.; Daniyal, W.M.E.M.M. Cationically modified nanocrystalline cellulose/carboxyl-functionalized graphene quantum dots nanocomposite thin film: Characterization and potential sensing application. Crystals 2020, 10, 875. [CrossRef]

47. Rosddi, N.N.M.; Fen, Y.W.; Omar, N.A.S.; Anas, N.A.A.; Hashim, H.S.; Ramdzan, N.S.M.; Fauzi, N.I.M.; Anuar, M.F.; Daniyal, W.M.E.M.M. Glucose detection by gold modified carboxyl-functionalized graphene quantum dots-based surface plasmon resonance. Optik 2021, 239, 166779. [CrossRef]

48. Anas, N.A.A.; Fen, Y.W.; Yusof, N.A.; Omar, N.A.S.; Ramdzan, N.S.M.; Daniyal, W.M.E.M.M. Investigating the properties of cetyltrimethylammonium bromide/hydroxylated graphene quantum dots thin film for potential optical detection of heavy metal ions. Materials 2020, 13, 2591. [CrossRef]

49. Saleviter, S.; Fen, Y.W.; Omar, N.A.S.; Zainudin, A.A.; Daniyal, W.M.E.M.M. Optical and structural characterization of immobilized 4-(2-pyridylazo) resorcinol in chitosan-graphene oxide composite thin film and its potential for $\mathrm{Co}_{2}+$ sensing using surface plasmon resonance technique. Results Phys. 2018, 11, 118-122. [CrossRef]

50. Anas, N.A.A.; Fen, Y.W.; Omar, N.A.S.; Daniyal, W.M.E.M.M.; Ramdzan, N.S.M.; Saleviter, S. Development of graphene quantum dots-based optical sensor for toxic metal ion detection. Sensors 2019, 19, 3850. [CrossRef]

51. Daniyal, W.M.E.M.M.; Fen, Y.W.; Saleviter, S.; Chanlek, N.; Nakajima, H.; Abdullah, J.; Yusof, N.A. X-ray photoelectron spectroscopy analysis of chitosan-graphene oxide-based composite thin films for potential optical sensing applications. Polymers 2021, 13, 478. [CrossRef]

52. Saleviter, S.; Fen, Y.W.; Daniyal, W.M.E.M.M.; Abdullah, J.; Sadrolhosseini, A.R.; Omar, N.A.S. Design and analysis of surface plasmon resonance optical sensor for determining cobalt ion based on chitosan-graphene oxide decorated quantum dots-modified gold active layer. Opt. Express 2019, 27, 32294-32307. [CrossRef]

53. Fauzi, N.I.M.; Fen, Y.W.; Omar, N.A.S.; Saleviter, S.; Daniyal, W.M.E.M.M.; Hashim, H.S.; Nasrullah, M. nanostructured chitosan/maghemite composites thin film for potential optical detection of mercury ion by surface plasmon resonance investigation. Polymers 2020, 12, 1497. [CrossRef] [PubMed]

54. Anas, N.A.A.; Fen, Y.W.; Yusof, N.A.; Omar, N.A.S.; Daniyal, W.M.E.M.M.; Ramdzan, N.S.M. Highly sensitive surface plasmon resonance optical detection of ferric ion using CTAB/hydroxylated graphene quantum dots thin film. J. Appl. Phys. 2020, 128, 083105. [CrossRef]

55. Hashim, H.S.; Fen, Y.W.; Omar, N.A.S.; Abdullah, J.; Daniyal, W.M.E.M.M.; Saleviter, S. Detection of phenol by incorporation of gold modified-enzyme based graphene oxide thin film with surface plasmon resonance technique. Opt. Express 2020, 28, 9738-9752. [CrossRef]

56. Daniyal, W.M.E.M.M.; Fen, Y.W.; Fauzi, N.I.M.; Hashim, H.S.; Ramdzan, N.S.M.; Omar, N.A.S. Recent advances in surface plasmon resonance optical sensors for potential application in environmental monitoring. Sens. Mater. 2020, 32, 4191-4200.

57. Saleviter, S.; Fen, Y.W.; Sheh Omar, N.A.; Daniyal, W.M.E.M.M.; Abdullah, J.; Mat Zaid, M.H. Structural and optical studies of cadmium sulfide quantum dot-graphene oxide-chitosan nanocomposite thin film as a novel SPR spectroscopy active layer. $J$. Nanomater. 2018, 2018, 4324072. [CrossRef]

58. Ramdzan, N.S.M.; Fen, Y.W.; Anas, N.A.A.; Omar, N.A.S.; Saleviter, S. Development of biopolymer and conducting polymer-based optical sensors for heavy metal ion detection. Molecules 2020, 25, 2548. [CrossRef]

59. Fen, Y.W.; Yunus, W.M.M.; Yusof, N.A. Surface plasmon resonance optical sensor for detection of $\mathrm{Pb}^{2+}$ based on immobilized p-tert-butylcalix [4] arene-tetrakis in chitosan thin film as an active layer. Sens. Actuators B Chem. 2012, 171, 287-293. [CrossRef]

60. Sadrolhosseini, A.R.; Naseri, M.; Kamari, H.M. Surface plasmon resonance sensor for detecting of arsenic in aqueous solution using polypyrrole-chitosan-cobalt ferrite nanoparticles composite layer. Opt. Commun. 2017, 383, 132-137. [CrossRef]

61. Fen, Y.W.; Yunus, W.M.M. Utilization of Chitosan-based sensor thin films for the detection of lead ion by surface plasmon resonance optical sensor. IEEE Sens. J. 2013, 13, 1413-1418. [CrossRef]

62. Fen, Y.W.; Yunus, W.M.M.; Moksin, M.M.; Talib, Z.A.; Yusof, N.A. Surface plasmon resonance optical sensor for mercury ion detection by crosslinked chitosan thin film. J. Optoelectron. Adv. Mater. 2011, 13, 279-285.

63. Huq, T.; Salmieri, S.; Khan, A.; Khan, R.A.; Le, C.; Riedl, B.; Fraschini, C.; Bouchard, J.; Uribe-calderon, J.; Kamal, M.R.; et al. Nanocrystalline cellulose (NCC) reinforced alginate based biodegradable nanocomposite film. Carbohydr. Polym. 2012, 90, 1757-1763. [CrossRef]

64. Tehrani, A.D.; Basiryan, A. Dendronization of cellulose nanowhisker with cationic hyperbranched dendritic polyamidoamine. Carbohydr. Polym. 2015, 120, 46-52. [CrossRef]

65. Azrina, Z.A.Z.; Beg, M.D.H.; Rosli, M.Y.; Ramli, R.; Alam, A.K.M.M. Modification of nanocrystalline cellulose (NCC) by hyperbranched polymer. Indian J. Sci. Technol. 2017, 10, 1-5. [CrossRef]

66. Selvaganesh, S.V.; Mathiyarasu, J.; Phani, K.L.N.; Yegnaraman, V. Chemical synthesis of PEDOT—Au nanocomposite. Nanoscale Res. Lett. 2007, 2, 546-549. [CrossRef]

67. Gaspar, D.; Fernandes, S.; de Oliveira, A.; Fernandes, J.; Grey, P.; Pontes, R.; Pereira, L.; Martins, R.; Godinho, M.; Fortunato, E. Nanocrystalline cellulose applied simultaneously as the gate dielectric and the substrate inflexible field effect transistors. Nanotechnology 2014, 25, 094008. [CrossRef]

68. Abidin, S.N.J.S.Z.; Azman, N.H.N.; Kulandaivalu, S.; Sulaiman, Y. Poly(3,4-ethylenedioxythiophene) Doped with Carbon Materials for High-Performance Supercapacitor: A Comparison Study. J. Nanomater. 2017, 2017, 13. 
69. Elazzouzi-hafraoui, S.; Nishiyama, Y.; Putaux, J.; Heux, L.; Dubreuil, F.; Rochas, C. The shape and size distribution of crystalline nanoparticles prepared by acid hydrolysis of native cellulose. Biomacromolecules 2008, 9, 57-65. [CrossRef] [PubMed]

70. Sakunpongpitiporn, P.; Phasuksom, K.; Paradee, N.; Sirivat, A. Facile synthesis of highly conductive PEDOT: PSS via surfactant templates. R. Soc. Chem. 2019, 9, 6363-6378.

71. Roshidi, M.D.A.; Fen, Y.W.; Daniyal, W.M.E.M.M.; Omar, N.A.S.; Zulholinda, M. Structural and optical properties of chitosanpoly(amidoamine) dendrimer composite thin film for potential sensing $\mathrm{Pb}^{2+}$ using an optical spectroscopy. Optik 2019, 185, 351-358. [CrossRef]

72. Ramdzan, N.S.M.; Fen, Y.W.; Omar, N.A.S.; Anas, N.A.A.; Daniyal, W.M.E.M.M.; Saleviter, S.; Zainudin, A.A. Optical and surface plasmon resonance sensing properties for chitosan/carboxyl-functionalized graphene quantum dots thin film. Optik 2019, 178, 802-812. [CrossRef]

73. Fen, Y.W.; Yunus, W.M.M.; Talib, Z.A.; Yusof, N.A. Development of surface plasmon resonance sensor for determining zinc ion using novel active nanolayers as probe. Spectrochim. Acta-Part A Mol. Biomol. Spectrosc. 2015, 134, 48-52. [CrossRef] [PubMed]

74. Zainudin, A.A.; Fen, Y.W.; Yusof, N.A.; Al-Rekabi, S.H.; Mahdi, M.A.; Omar, N.A.S. Incorporation of surface plasmon resonance with novel valinomycin doped chitosan-graphene oxide thin film for sensing potassium ion. Spectrochim. Acta-Part A Mol. Biomol. Spectrosc. 2018, 191, 111-115. [CrossRef] [PubMed]

75. Omar, N.A.S.; Fen, Y.W.; Saleviter, S.; Daniyal, W.M.E.M.M.; Anas, N.A.A.; Ramdzan, N.S.M.; Roshidi, M.D.A. Development of a graphene-based surface plasmon resonance optical sensor chip for potential biomedical application. Materials 2019, $12,1928$. [CrossRef]

76. Fen, Y.W.; Yunus, W.M.M.; Yusof, N.A. Detection of mercury and copper ions using surface plasmon resonance optical sensor. Sens. Mater. 2011, 23, 325-334.

77. Fen, Y.W.; Yunus, W.M.M. Surface plasmon resonance spectroscopy as an alternative for sensing heavy metal ions: A review. Sens. Rev. 2013, 33, 305-314.

78. Daniyal, W.M.E.M.M.; Fen, Y.W.; Abdullah, J.; Sadrolhosseini, A.R.; Saleviter, S.; Omar, N.A.S. Exploration of surface plasmon resonance for sensing copper ion based on nanocrystalline cellulose-modified thin film. Opt. Express 2018, 26, 34880. [CrossRef]

79. Fen, Y.W.; Yunus, W.M.M.; Yusof, N.A.; Ishak, N.S.; Omar, N.A.S.; Zainudin, A.A. Preparation, characterization and optical properties of ionophore doped chitosan biopolymer thin film and its potential application for sensing metal ion. Optik 2015, 126, 4688-4692. [CrossRef]

80. Babakhani, B.; Ivey, D.G. Improved capacitive behavior of electrochemically synthesized Mn oxide/PEDOT electrodes utilized as electrochemical capacitors. Electrochim. Acta 2010, 55, 4014-4024. [CrossRef]

81. Chanthaanont, P.; Sirivat, A. Effect of transition metal ion-exchanged into the zeolite $\mathrm{Y}$ on electrical conductivity and response of PEDOT-PSS/MY composites toward $\mathrm{SO}_{2}$. Adv. Polym. Technol. 2013, 32, 21367. [CrossRef]

82. Chen, W.C.; Liu, C.L.; Yen, C.T.; Tsai, F.C.; Tonzola, C.J.; Olson, N.; Jenekhe, S.A. Theoretical and experimental characterization of small band gap poly(3,4-ethylenedioxythiophene methine)s. Macromolecules 2004, 37, 5959-5964. [CrossRef]

83. Byun, K.M.; Yoon, S.J.; Kim, D.; Kim, S.J. Sensitivity analysis of a nanowire-based surface plasmon resonance biosensor in the presence of surface roughness. J. Opt. Soc. Am. A 2007, 24, 522-529. [CrossRef] [PubMed]

84. Ashery, A.; Said, G.; Arafa, W.A.; Gaballah, A.E.H.; Farag, A.A.M. Structural and optical characteristics of PEDOT/n-Si heterojunction diode. Synth. Met. 2016, 214, 92-99. [CrossRef]

85. Oluyamo, S.S.; Akinboyewa, L.O.; Fuwape, I.A.; Olusola, O.I.; Adekoya, M.A. Influence of nanocellulose concentration on the tunability of energy bandgap of cadmium telluride thin films. Cellulose 2020, 27, 8147-8153. [CrossRef]

86. Ramdzan, N.S.M.; Fen, Y.W.; Omar, N.A.S.; Anas, N.A.A.; Liew, J.Y.C.; Daniyal, W.M.E.M.M.; Hashim, H.S. Detection of mercury ion using surface plasmon resonance spectroscopy based on nanocrystalline cellulose/poly (3,4-ethylenedioxythiophene) thin film. Measurement 2021, 182, 109728. [CrossRef]

87. Shalabney, A.; Abdulhalim, I. Sensitivity-enhancement methods for surface plasmon sensors. Laser Photonics Rev. 2011, 5, 571-606. [CrossRef]

88. Anas, N.A.A.; Fen, Y.W.; Omar, N.A.S.; Ramdzan, N.S.M.; Daniyal, W.M.E.M.M.; Saleviter, S.; Zainudin, A.A. Optical properties of chitosan/hydroxyl-functionalized graphene quantum dots thin film for potential optical detection of ferric (III) ion. Opt. Laser Technol. 2019, 120, 105724. [CrossRef]

89. Daniyal, W.M.E.M.M.; Fen, Y.W.; Abdullah, J.; Sadrolhosseini, A.R.; Saleviter, S.; Omar, N.A.S. Label-free optical spectroscopy for characterizing binding properties of highly sensitive nanocrystalline cellulose-graphene oxide based nanocomposite towards nickel ion. Spectrochim. Acta-Part A Mol. Biomol. Spectrosc. 2019, 212, 25-31. [CrossRef] 